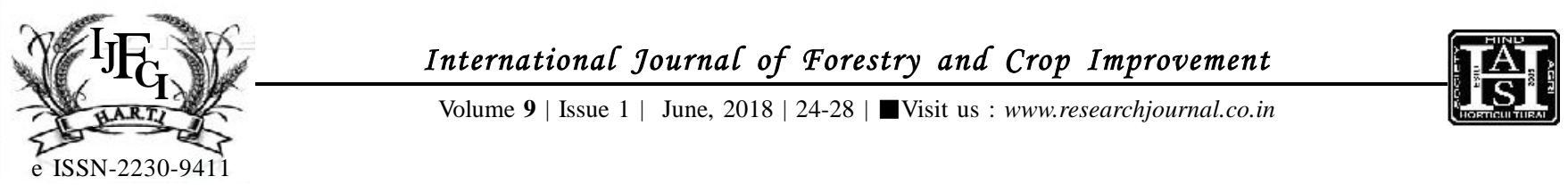

\title{
Response of wheat (Triticum aestivum L.) to integrated nitrogen management and their residual effect on succeeding forage cowpea (Vigna unguiculata L.)
}

\author{
P. K. Suryawanshi, V. D. Pagar, A.C. Sadhu and R.S. Kalasare
}

\begin{abstract}
Field experiment was conducted at B. A. College of Agriculture, Anand (Gujarat) during Rabi season of 2012-13 and 2013-14 to evaluate Response of wheat (Triticum aestivum L.) to integrated nitrogen management and their residual effect on succeeding forage cowpea (Vigna unguiculata L.). Seven nitrogen management treatments through chemical fertilizer and manures and three levels of bio-fertilizer inoculation were replicated three times. Result of the experiment revealed that $75 \%$ RDN $+25 \%$ RDN from FYM when applied in the wheat it produced higher growth, yield attributing characters, grain yield (3716 kg $\mathrm{ha}^{-1}$ ) and net returns (Rs. $\left.29304 \mathrm{ha}^{-1}\right)$ while, application of 100\% RDN (120 kg N) produced higher straw yield (7771 kg ha-1) of wheat. The seed inoculation with Azotobacter chroococum and Azospirillum lipoferum maximize the growth, yield attributing characters, yields of wheat $\left(3328 \mathrm{~kg} \mathrm{ha}^{-1}\right)$ and secured higher net return (Rs. $\left.21932 \mathrm{ha}^{-1}\right)$. However, green fodder $\left(275 \mathrm{q} \mathrm{ha}^{-1}\right)$, dry matter yield of succeeding forage cowpea $\left(66 \mathrm{q} \mathrm{ha}^{-1}\right)$ were significantly influenced by residual effect of treatment $25 \% \mathrm{RDN}+25 \%$ from FYM $+25 \%$ from VC $+25 \%$ from CC. Azotobacter + Azospirilium inoculation treatment were maximize green fodder 250 and dry fodder yield $60 \mathrm{q} \mathrm{ha}^{-1}$ of wheat-forage cowpea sequence in sandy loam soils under middle Gujarat agro-climatic conditions.
\end{abstract}

KEY WORDS : Wheat, Forage cowpea, INM, Biofertilizer inoculation, Residual effect

HOW TO CITE THIS ARTICLE : Suryawanshi, P.K., Pagar, V.D., Sadhu, A.C. and Kalasare, R.S. (2018). Response of wheat (Triticum aestivum L.) to integrated nitrogen management and their residual effect on succeeding forage cowpea (Vigna unguiculata L.). Internat. J. Forestry \& Crop Improv., 9 (1) : 24-28, DOI: 10.15740/HAS/IJFCI/9.1/24-28. Copyright@ 2018: Hind Agri-Horticultural Society.

Article Chronical : Received : 06.12.2017; Revised : 18.05.2018; Accepted : 25.05.2018

\section{MEMBERS OF RESEARCH FORUM}

Address of the Correspondence : P.K. Suryawanshi, H.H. Sri Sri Muralidhara Swamiji College of Agriculture, Malegaon Camp, Nashik (M.S.) India Email: panksurya0923@gmail.com Address of the Coopted Authors : V.D. Pagar and A.C. Sadhu, H.H. Sri Sri Muralidhara Swamiji College of Horticulture, Malegaon Camp, Nashik (M.S.) India

R. S. Kalasare, Department of Agronomy, B.A. College of Agriculture, Anand Agricultural University, Anand (Gajarat) India 